\title{
Synthesis, Spectral Characterization, and Antiproliferative Studies of Mixed Ligand Titanium Complexes of Adamantylamine
}

\author{
Raj Kaushal, ${ }^{1}$ Nitesh Kumar, ${ }^{1}$ Ashun Chaudhary, ${ }^{2}$ Saroj Arora, ${ }^{2}$ and Pamita Awasthi ${ }^{1}$ \\ ${ }^{1}$ Department of Chemistry, National Institute of Technology, Hamirpur, Himachal Pradesh 177005, India \\ ${ }^{2}$ Department of Botanical and Environmental Sciences, Guru Nanak Dev University, Amritsar, Punjab 143005, India \\ Correspondence should be addressed to Nitesh Kumar; niteshnit6@gmail.com
}

Received 14 October 2013; Revised 9 January 2014; Accepted 9 January 2014; Published 27 February 2014

Academic Editor: Ian Butler

Copyright (C) 2014 Raj Kaushal et al. This is an open access article distributed under the Creative Commons Attribution License, which permits unrestricted use, distribution, and reproduction in any medium, provided the original work is properly cited.

Titanium complexes have been synthesized by the reaction between titanium tetrachloride $\left(\mathrm{TiCl}_{4}\right)$, respective bidentate ligand $\left[4,4^{\prime}\right.$ -dimethoxy-2,2' -bipyridine (bpome), 6,6'-dimethyl-2,2' -bipyridine (dpme), 1,2-diaminocyclohexane (dach), 1,10-phenanthroline (phen), and benzoylacetone (bzac)], and adamantylamine (ada) in 1:2:2 molar ratios, respectively. The structure of synthesized complexes was confirmed using elemental analysis, FTIR, UV-visible, ${ }^{1} \mathrm{H}$ NMR, and mass spectrometry techniques. The nanocrystalline nature of complexes was confirmed by powder XRD study. The complexes were evaluated for cytotoxic potential in HeLa (cervical), C6 (glioma), and CHO (Chinese hamster ovarian) cell lines. The complex E was found to be more effective cytotoxic agent against HeLa cell line with an $\mathrm{IC}_{50}$ value of $4.06 \mu \mathrm{M}$. Furthermore, the effect of synthesized complexes was studied on different stages of the cell cycle in $\mathrm{CHO}$ cells. All complexes exhibited the dose dependent increase in cytotoxicity. The results have shown an increase in sub- $\mathrm{G}_{0}$ population with increase in concentration which is an indicative measure of apoptosis.

\section{Introduction}

The discovery of cisplatin, a metal (platinum) based anticancer drug by Rosenberg et al. in 1965, has created interest in the development of metal based anticancer drugs [1-3]. The effect of transition metal complexes, other than platinum such as ruthenium [4-8], palladium [9-13], gold [14, 15], and titanium [16-25] has also been studied on several cancer cell lines. In addition to cisplatin, many other platinum based drugs,namely, carboplatin, oxaliplatin, tetraplatin, and satraplatin [3], and nonplatinum based drugs, namely, budotitane, titanocene dichloride [16], NAMI-A, KP1019 [2629], and auranofin [14] have shown remarkable results. Out of these, the first nonplatinum anticancer drugs were budotitane and titanocene dichloride which are titanium based drugs [16]. These titanium complexes offer an alternative to chemotherapy, although these complexes do not follow a mechanism similar to that of other metal complexes. Previous studies have revealed that titanium compounds are effective against those cell lines which are resistant to platinum based drugs and kill the cancer cells through apoptosis. It has also been confirmed that lability of ligand is not a mandatory condition for a compound to show cytotoxicity [30], but other ligand properties have been found to be necessary for this activity [31]. It is well established that ligands having electron donating atom(s) show increased cytotoxicity due to enhanced coordination capacity $[32,33]$. Since few efforts have been made towards the synthesis and use of titanium complexes as chemotherapeutic agents, this is an important area of research. In the present work, we report the synthesis, structural characterization, and antiproliferative potential of some of titanium complexes.

\section{Experimental Section}

2.1. Materials and Methods. Ligands and titanium tetrachloride used were obtained from Sigma Aldrich. All the solvents were of AR grade (Merck) and purified by standard procedure before use and stored over $4 \AA$ molecular sieves. Purity of ligands was checked by checking their melting points. Elemental 
analyses were performed by using Perkin-Elmer, Series 2400 . The UV-visible spectra of the complexes were recorded on Perkin Elmer Lambda 750 in the range of $200-800 \mathrm{~nm}$ and FTIR Spectra were recorded from $4000-200 \mathrm{~cm}^{-1}$ on Perkin Elmer 1600. The mass spectrum was recorded by using the electron spray ionization technique on Waters Micromas Q Tof Micro. ${ }^{1} \mathrm{H}$ NMR Spectra were recorded on Brucker Avance $400 \mathrm{MHz}$ spectrometer. Crystalline nature of the complexes has been confirmed by powder XRD technique on Philips $1710 \mathrm{X}$-ray diffractometer.

\subsection{Synthetic Procedures (A-E)}

2.2.1. Synthesis of Bis(adamantylamino)bis-( $4,4^{\prime}$-dimethoxy$2,2^{\prime}$-bipyridyl)titanium(II), Ti(ada $)_{2}(\text { bpome })_{2}$, (A). To a colorless solution of $4,4^{\prime}$-dimethoxy-2,2' -bipyridyl ( $0.45 \mathrm{~g}$, $2.1 \mathrm{mmol}$ ) in $25 \mathrm{~mL}$ of toluene, a pale yellow colored solution of titanium tetrachloride $(0.2 \mathrm{~g}, 1.05 \mathrm{mmol})$ in $25 \mathrm{~mL}$ of toluene was added dropwise with continuous stirring under ice cold conditions. The reaction mixture was stirred for $2 \mathrm{~h}$ followed by refluxing for $10 \mathrm{~h}$ till the evolution of chlorine gas ceased. The evolution of chlorine gas was checked by passing the gas through a potassium iodide solution which results in reddish brown color of potassium iodide due to liberation of iodine. After removing solvent through vacuum distillationcompound was dried under vacuum. A light yellow colored solid compound $\left[\mathrm{TiCl}_{2}\right.$ (bpome) $\left.{ }_{2}\right]$ was obtained. Yield: $0.5 \mathrm{~g}$ $(86.2 \%)$. Now, to a solution of $\mathrm{TiCl}_{2}$ (bpome $)_{2}(0.5 \mathrm{~g}$, $0.91 \mathrm{mmol})$ in $25 \mathrm{~mL}$ of toluene, adamantylamine $(0.27 \mathrm{~g}$, $1.81 \mathrm{mmol}$ ) in $25 \mathrm{~mL}$ of toluene was added dropwise with continuous stirring. The reaction mixture was stirred for $2 \mathrm{~h}$ and refluxed for $14 \mathrm{~h}$ till the evolution of $\mathrm{HCl}$ gas ceased. The evolution of $\mathrm{HCl}$ gas was confirmed by passing the gas through an ammonia solution which results in white dense fumes of ammonium chloride. The excess solvent was removed by vacuum distillation and the compound was washed with petroleum ether. The compound was dried under vacuum. A cream colored solid powder was obtained which was recrystallised in methanol. Yield: $0.45 \mathrm{~g}(64.28 \%)$. $\mathrm{TiC}_{44} \mathrm{H}_{54} \mathrm{~N}_{6} \mathrm{O}_{4}$ : elemental anal. Calcd (\%): C 67.67, H 7.17, N 10.76; found (\%): C 66.71, H 7.05, N 10.52.FTIR (KBr, $\mathrm{cm}^{-1}$ ) $\bar{\nu}: 3388$ (NH Stretching), 3015 (aromatic CH stretching), 2927 ( $\mathrm{CH}$ stretching), 1629 (C=C stretching), $1522(\mathrm{C}=\mathrm{N}$ stretching), 1449 (NH bending) 1313, 1229 (CH bending), 906, 809 (CH out of plane deformation), 452 (Ti-N stretching). ${ }^{1} \mathrm{H}$ NMR (DMSO, $400 \mathrm{MHz}$ ): adamantylamine $\delta, \mathrm{ppm}=2.1(\mathrm{~s}$, $\mathrm{NH}), 1.86\left(\mathrm{~d},{ }^{3} \mathrm{~J}=1.96 \mathrm{~Hz}, \mathrm{CH}_{2}\right.$ protons $), 1.66,1.59,\left(\mathrm{dd},{ }^{3} \mathrm{~J}=\right.$ 12.36, 29.6 Hz CH protons). 4, $4^{\prime}$-Dimethoxy-2, $2^{\prime}$-bipyridine $\delta, \mathrm{ppm}=8.66\left(\mathrm{~d},{ }^{3} \mathrm{~J}=6.16 \mathrm{~Hz}, 4 \mathrm{H}, \mathrm{H}^{6}\right), 7.96\left(\mathrm{~s}, 4 \mathrm{H}, \mathrm{H}^{3}\right), 7.37$ $\left(\mathrm{d},{ }^{3} \mathrm{~J}=8 \mathrm{~Hz}, 4 \mathrm{H}, \mathrm{H}^{5}\right), 4.09\left(\mathrm{~s}, 12 \mathrm{H}, \mathrm{OCH}_{3}\right)$.

2.2.2. Synthesis of Bis(adamantylamino)bis-(6,6'-dimethyl$2,2^{\prime}$-bipyridyl)titanium(II), Ti(ada $)_{2}(d p m e)_{2}$, (B). The complex was synthesized in accordance to the procedure used for complex A. Yield: $0.4 \mathrm{~g}(84.38 \%)$. $\mathrm{TiC}_{44} \mathrm{H}_{54} \mathrm{~N}_{6}$ : elemental anal. Calcd (\%): C 73.70, H 7.81, N 11.72; found (\%): C 73.91, $\mathrm{H}$ 7.94, N 11.54. FTIR (KBr, cm $\left.{ }^{-1}\right) \bar{v}: 3336$ (NH stretching), 3071 (aromatic $\mathrm{CH}$ stretching), 2925 (CH stretching), 1644
( $\mathrm{C}=\mathrm{C}$ stretching), 1506 ( $\mathrm{C}=\mathrm{N}$ stretching), 1441 ( $\mathrm{NH}$ bending) 1271, 1117 (CH bending), 906, 801 (CH out of plane deformation), 404 (Ti-N stretching). ${ }^{1} \mathrm{H}$ NMR (DMSO, $400 \mathrm{MHz}$ ): adamantylamine $\delta, \mathrm{ppm}=2.12(\mathrm{~s}, \mathrm{NH}), 1.91\left(\mathrm{~d},{ }^{3} \mathrm{~J}=2.12 \mathrm{~Hz}\right.$, $\mathrm{CH}_{2}$ protons), $1.69,1.64$, (dd, ${ }^{3} J=12.6,22.6 \mathrm{~Hz} \mathrm{CH}$ protons). $6,6^{\prime}$-Dimethyl-2,2' -bipyridine $\delta, \mathrm{ppm}=8.5\left(\mathrm{~d},{ }^{3} \mathrm{~J}=7.96 \mathrm{~Hz}\right.$, $\left.4 \mathrm{H}, \mathrm{H}^{5}\right), 8.23\left(\mathrm{t},{ }^{3} \mathrm{~J}=7.8,7.8 \mathrm{~Hz} 4 \mathrm{H}, \mathrm{H}^{4}\right), 7.68\left(\mathrm{~d},{ }^{3} \mathrm{~J}=7.8 \mathrm{~Hz}\right.$, $\left.4 \mathrm{H}, \mathrm{H}^{3}\right), 2.89\left(\mathrm{~s}, 12 \mathrm{H}, \mathrm{CH}_{3}\right)$.

2.2.3. Synthesis of Bis(adamantylamino)bis-(1,2-diaminocyclohexane)titanium(II), Ti(ada $)_{2}(\text { dach })_{2},(\mathrm{C})$. The complex C was synthesized similarly to complex A. Yield $=0.48 \mathrm{~g}$ (87.2\%). $\mathrm{TiC}_{32} \mathrm{H}_{58} \mathrm{~N}_{6}$ : elemental anal. Calcd (\%): C 66.63, H 10.41, N 14.57; found (\%): C 65.77, H 10.23, N 14.72. FTIR (KBr, $\mathrm{cm}^{-1}$ ) $\bar{v}: 3379$ (NH stretching), 2925, 2900 (CH stretching), 1595 (C-N stretching), 1522 (NH bending), 1360, 1311 (CH bending), 1084, 1020 (CH out of plane deformation), 444 (Ti$\mathrm{N}$ stretching). ${ }^{1} \mathrm{H}$ NMR $\left(\mathrm{D}_{2} \mathrm{O}, 400 \mathrm{MHz}\right)$ : adamantylamine $\delta$, $\mathrm{ppm}=2.09(\mathrm{~s}, \mathrm{NH}), 1.7,{ }^{3} \mathrm{~J}=4\left(\mathrm{~d}, \mathrm{CH}_{2}\right.$ protons $), 1.63,1.55$, (dd, ${ }^{3} J=12.52,36.76 \mathrm{CH}$ protons). 1,2-Diaminocyclohexane $\delta, \mathrm{ppm}=3.63\left(\mathrm{t},{ }^{3} J=4.8,4.64 \mathrm{CH}\right), 3.3\left(\mathrm{~m}, \mathrm{NH}_{2}\right), 2.01,1.76$, $1.68,1.3\left(\mathrm{H}^{3}, \mathrm{H}^{6}, \mathrm{H}^{4}, \mathrm{H}^{5}\right)$.

2.2.4. Synthesis of Bis(adamantylamino)bis-(1,10-phenanthroline)titanium(II), $\quad \mathrm{Ti}(\mathrm{ada})_{2}(\text { phen })_{2}, \quad$ (D). The procedure described above for complex A was followed for the synthesis of complex D. Yield: $0.42 \mathrm{~g}(87.5 \%)$. $\mathrm{TiC}_{44} \mathrm{H}_{46} \mathrm{~N}_{6}$ : elemental anal. Calcd (\%): C 74.55, H 6.77, N 11.85; found (\%): C 74.46, H 6.42, N 11.52. FTIR (KBr, cm $\left.{ }^{-1}\right) \bar{v}: 3412$ (NH stretching), 3039 (aromatic $\mathrm{CH}$ stretching), 2927 ( $\mathrm{CH}$ stretching), 1612 (C=C stretching), 1514 ( $\mathrm{N}-\mathrm{H}$ bending), 1449 (C=N stretching), 1368, 1319 (CH bending), 1084 (CH out of plane deformation), 411 (Ti-N stretching). ${ }^{1} \mathrm{H} \quad \mathrm{NMR} \quad\left(\mathrm{D}_{2} \mathrm{O}, \quad 400 \mathrm{MHz}\right)$ : adamantylamine $\delta, \mathrm{ppm}=2.04(\mathrm{~s}, \mathrm{NH}), 1.75\left(\mathrm{~d},{ }^{3} \mathrm{~J}=2.52\right.$, $\mathrm{CH}_{2}$ protons), 1.61, 1.55, (dd, ${ }^{3} \mathrm{~J}=24.8 \mathrm{CH}$ protons). $1,10-$ Phenanthroline $\delta$, ppm $=8.56\left(\mathrm{~d},{ }^{3} J=7.43,4 \mathrm{H}, \mathrm{H}^{2} \& \mathrm{H}^{9}\right), 7.7$ $\left(\mathrm{s}, 4 \mathrm{H}, \mathrm{H}^{5} \& \mathrm{H}^{6}\right), 7.4\left(\mathrm{~d},{ }^{3} \mathrm{~J}=9.28,4 \mathrm{H}, \mathrm{H}^{4} \& \mathrm{H}^{7}\right), 6.8\left(\mathrm{dd},{ }^{3} J=\right.$ $\left.28,40,4 \mathrm{H}, \mathrm{H}^{3} \& \mathrm{H}^{8}\right)$.

2.2.5. Synthesis of Bis(adamantylamino)bis(benzoylacetonato) titanium $(I V)$, Ti $(a d a)_{2}(b z a c)_{2}$, (E). The procedure for the synthesis of complex A was followed for the preparation of complex E. However, there was evolution of $\mathrm{HCl}$ gas in both the steps. Yield: $0.43 \mathrm{~g}(86 \%) . \mathrm{TiC}_{40} \mathrm{H}_{48} \mathrm{~N}_{2} \mathrm{O}_{2}$ : elemental anal. Calcd (\%): C 71.61, H 7.45, N 4.17; found (\%): C 71.70, $\mathrm{H}$ 7.27, N 4.10. FTIR (KBr, $\left.\mathrm{cm}^{-1}\right) \bar{v}: 3379$ (NH stretching), 2933, 2866 ( $\mathrm{CH}$ stretching), 1612 ( $\mathrm{C}=\mathrm{O}$ stretching), 1522 (C=C stretching), 1449 ( $\mathrm{NH}$ bending), 1109, 1004 (C-H bending), 557 (Ti-O stretching), 427 ( $\mathrm{Ti}-\mathrm{N}$ stretching). ${ }^{1} \mathrm{H} \mathrm{NMR}\left(\mathrm{D}_{2} \mathrm{O}\right.$, $400 \mathrm{MHz})$ : adamantylamine $\delta, \mathrm{ppm}=2(\mathrm{~s}, \mathrm{NH}), 1.71\left(\mathrm{~d},{ }^{3} \mathrm{~J}\right.$ $=2.56, \mathrm{CH}_{2}$ protons), 1.58, 1.49, (dd, ${ }^{3} J=12.56,12.08 \mathrm{CH}$ protons). Benzoylacetone $\delta$, ppm $\mathrm{C}_{6} \mathrm{H}_{5}: \delta=8.08\left(\mathrm{~d},{ }^{3} J=7.52\right.$, $4 \mathrm{H}, \mathrm{H}^{2}$ and $\left.\mathrm{H}^{6}\right), 7.96\left(\mathrm{t},{ }^{3} \mathrm{~J}=7.16,4.28,4 \mathrm{H}, \mathrm{H}^{3}\right.$ and $\left.\mathrm{H}^{5}\right), 7.6$ $\left(\mathrm{t},{ }^{3} \mathrm{~J}=7.64,7.28,2 \mathrm{H}, \mathrm{H}^{4}\right), 3.92$ (s, $\mathrm{CH}$ protons), 2.5 (s, $\mathrm{CH}_{3}$ protons). 


$$
\begin{aligned}
& \begin{aligned}
\mathrm{TiCl}_{4}+2 \mathrm{~L} 1 \frac{\text { Toluene }}{\text { stirring/refluxing }} & \mathrm{TiCl}_{2}(\mathrm{~L} 1)_{2}+\mathrm{Cl}_{2} \uparrow \\
& +2 \mathrm{~L} \downarrow \begin{array}{c}
\text { Toluene } \\
\text { stirring/refluxing }
\end{array}
\end{aligned} \\
& \mathrm{Ti}(\mathrm{L})_{2}(\mathrm{~L} 1)_{2}+2 \mathrm{HCl} \uparrow
\end{aligned}
$$

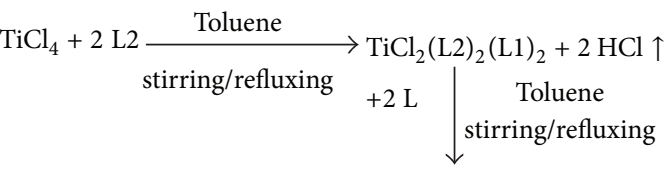

$$
\begin{aligned}
& \mathrm{Ti}(\mathrm{L})_{2}(\mathrm{~L} 2)_{2}+2 \mathrm{HCl} \uparrow
\end{aligned}
$$

Where, $\mathrm{L}=$ adamantylamine

$\mathrm{L} 1=4,4^{\prime}$-dimethoxy-2, $2^{\prime}$-bipyridine

$=6,6^{\prime}$-dimethyl-2, $2^{\prime}$-bipyridine

$=1,2$-diaminocyclohexane

$=1,10$-phenanthroline

L2 = benzoylacetone

Scheme 1: General synthetic route for mixed ligand titanium complexes of adamantylamine.

\subsection{Cytotoxicity Studies}

2.3.1. Cell Lines and Culture. The cytotoxic studies of synthesized complexes were performed on HeLa (cervical cancer cell line), C6 (glioma), and CHO (Chinese hamster ovarian) cell line. The cells were grown in Dulbecco's Modified Eagle's Medium (DMEM) containing fetal calf serum (FCS) (10\%), penicillin (100 units/mL), and streptomycin $(100 \mu \mathrm{g} / \mathrm{mL})$ at $37^{\circ} \mathrm{C}$ with $90 \%$ humidity and $5 \% \mathrm{CO}_{2}$. The complexes were dissolved in dimethyl sulphoxide (DMSO) to prepare the solutions of different concentrations. The selected cell lines were treated with these solutions to calculate the $\mathrm{IC}_{50}$ values by using MTT (3-(4,5-dimethylthiazol-2-yl)-2,5diphenyltetrazolium bromide) assay while control cells received only DMSO.

2.3.2. MTT Assay. The growth inhibitory effect of newly synthesized titanium complexes on HeLa, C6, and $\mathrm{CHO}$ cells was determined by MTT assay [34]. For this, cells were supplemented in complete growth medium to get $1 \times 10^{5}$ cells $/ \mathrm{mL}$ and $100 \mu \mathrm{L}$ of cell suspension per well was seeded in tissue culture plate. The assay was carried out in 96 well plates in triplicate in which cells were treated with three different concentrations of complexes and incubated for $12 \mathrm{~h}$ in $\mathrm{CO}_{2}$ incubator. Thereafter, $20 \mu \mathrm{L}$ of freshly prepared MTT solution, $5 \mathrm{mgmL}^{-1}$ in PBS (phosphate buffered saline) after sterile filtering, was added to each well. Now, culture plates were stirred at $150 \mathrm{rpm}$ for $5 \mathrm{~min}$ to thoroughly mix MTT into the media. The plates were further incubated for $4 \mathrm{~h}$ at $37^{\circ} \mathrm{C}$ to allow metabolization of MTT. MTT formazan crystals were resuspended in $100 \mu \mathrm{L}$ of DMSO and plates were stirred for $20 \mathrm{~min}$ in order to dissolve formazan crystals and optical density was measured at $570 \mathrm{~nm}$. The phase contrast imaging was done by using Nikon Eclipse TS100 inverted microscope.

2.3.3. Cell Cycle Analysis. $1 \times 10^{6}$ cells/dish well was plated in 24 well plates which were allowed for adheration for $6 \mathrm{~h}$ and then treated with complexes at three different concentrations. After $24 \mathrm{~h}$ of treatment, cells were harvested from the plate. The cell suspension having $1 \times 10^{6}$ cells was centrifuged and the resultant cell pellet was resuspended in phosphate buffered saline $(1 \mathrm{~mL})$ solution. The cells were fixed in ice cold $70 \%$ ethanol and stained with propidium iodide followed by analysis on the FL-2 channel by BD Accuri C6 flow cytometer
(BD Biosciences Immunocytometry Systems, San Jose, CA). DNA content histograms and cell cycle phase distributions were modeled from at least 15,000 single events.

\section{Results and Discussion}

Synthesis of titanium complexes was carried out in two steps. In the first step, titanium tetrachloride reacted with respective bidentate ligand, that is, $4,4^{\prime}$-dimethoxy-2, $2^{\prime}$-bipyridine, $6,6^{\prime}$-dimethyl-2,2' -bipyridine, 1,2-diaminocyclohexane, 1,10 phenanthroline, and benzoylacetone which are coligands in 1:2 molar ratio under continuous stirring and refluxing by using toluene as a solvent. There was evolution of chlorine gas during the course of reaction. In the next step, respective titanium complexes reacted with main ligand (adamantylamine) in 1:2 molar ratio in the same solvent, which results in evolution of $\mathrm{HCl}$ gas [35] as shown in Scheme 1. Elemental analysis, that is, Titanium and chlorine estimation, was performed to check the composition by gravimetric and Volhard's method, respectively, and molecular weight was determined by Rast's camphor method (Table 1). The analytical data and spectroscopic characterization of complexes confirm the proposed structure of complexes. The proposed structure of complexes and their corresponding ligands has been shown in Table 2.

3.1. FTIR Spectra. The bands of FTIR were assigned by comparing the spectra of complexes with those of free ligands and were shown in Table 3. From the spectra of complexes, we have found that wave number of $\bar{\nu}_{\mathrm{C}-\mathrm{H}}$ band appearing around $2900-3000 \mathrm{~cm}^{-1}$ does not change much although the intensity of the band changes and gets weaker upon complexation with titanium metal. The absorption band due to $\bar{v}_{\mathrm{C}=\mathrm{C}}$ stretching at 1595,1578 , and $1603 \mathrm{~cm}^{-1}$ in the bidentate ligand of complexes A, B, and D gets shifted to 1629,1644 , and $1612 \mathrm{~cm}^{-1}$ (Table 3). The shift may be due to reduction in electron density after an increase in conjugation caused by complexation with titanium metal [36]. In previous studies, it has been observed that three factors, namely, field effect, steric effect, and ring strain, can cause shift in vibrational frequencies of complexes. Due to field effect [37], the value of force constant gets changed and there is change in vibration frequencies, due to steric effect [36], the conjugation in the complex is not completed which results in a shift in 
TABLE 1: Physical and analytical properties of titanium complexes.

\begin{tabular}{|c|c|c|c|c|c|}
\hline \multirow{2}{*}{ Complex } & \multirow{2}{*}{ Color } & \multirow{2}{*}{ Yield (\%) } & \multirow{2}{*}{ M.P. $\left({ }^{\circ} \mathrm{C}\right)$} & \multicolumn{2}{|c|}{ Experimental (Theortical) \% } \\
\hline & & & & $\mathrm{Ti}$ & MW \\
\hline $\mathrm{Ti}(\mathrm{ada})_{2}(\mathrm{bpome})_{2}(\mathrm{~A})$ & Cream & 64.2 & $205-210$ & $6.3(6.1)$ & $778(780)$ \\
\hline $\mathrm{Ti}(\mathrm{ada})_{2}(\mathrm{dpme})_{2}(\mathrm{~B})$ & Cream & 87.3 & $205-210$ & $7.1(6.6)$ & $713(716)$ \\
\hline $\operatorname{Ti}(\text { ada })_{2}(\text { dach })_{2}(\mathrm{C})$ & White & 87.2 & $225-230$ & $8.3(8.1)$ & $574(577)$ \\
\hline $\operatorname{Ti}(\text { ada })_{2}(\text { phen })_{2}(\mathrm{D})$ & Cream & 87.5 & $210-215$ & $6.0(6.6)$ & $705(708)$ \\
\hline $\mathrm{Ti}(\mathrm{ada})_{2}(\mathrm{bzac})_{2}(\mathrm{E})$ & Light Orange & 86 & $240-245$ & $7.8(7.1)$ & $668(670)$ \\
\hline
\end{tabular}

absorption frequencies to higher wave number, and due to ring strain in the molecule, more energy is required for vibration of bonds which results in shift of band towards higher wave number. The ring breathing vibration (around 800$900 \mathrm{~cm}^{-1}$ ) having more intensity gets shifted to higher wave number in complexes (around $1000 \mathrm{~cm}^{-1}$ ). All these changes can be assigned to the coordinated nature of bidentate ligand through nitrogen atoms $[12,13]$. The band formed around $3350-3400 \mathrm{~cm}^{-1}$ due to $\mathrm{N}-\mathrm{H}$ stretching of adamantylamine ring, while the occurrence of a strong band in the region $1600-1580 \mathrm{~cm}^{-1}$ in complex E may be assigned to stretching modes of $\bar{v}_{\mathrm{C}=\mathrm{O}}$ in benzoylacetone ligand. In complex $\mathrm{E}$ carbonyl groups are involved in bonding with the metal ion which is further supported by the appearance of an intense band at $\sim 557 \mathrm{~cm}^{-1}$ assignable to $\bar{\nu}_{\mathrm{M}-\mathrm{O}}$ vibration. Appearance of new bands at $452,404,444,411$, and $427 \mathrm{~cm}^{-1}$ in complexes $\mathrm{A}, \mathrm{B}, \mathrm{C}, \mathrm{D}$, and $\mathrm{E}$ shows that ligands are coordinated to the metal atom through nitrogen $[35,38]$ and the absence of bands in the region $385-340 \mathrm{~cm}^{-1}$ due to $\bar{\nu}_{\mathrm{Ti}-\mathrm{Cl}}$ bond in all complexes indicates the complete removal of chloride ions [39].

3.2. UV-Visible Spectra. The UV-visible spectra of the complexes (Figure 1) and ligands were recorded from a solid sample by using diffuse reflectance technique. The transitions observed in the UV-visible spectrum of complexes were due to intraligand charge transfer. The transition around $320-325 \mathrm{~nm}$ can be attributed to $n \rightarrow \pi^{*}$ transition in complexes A, B, D, and E get shifted to lower wavelength after coordination. However bands due to $\pi \rightarrow \pi^{*}$ around $240-245 \mathrm{~nm}$ remain almost at the same position even after coordination. Since in complex $\mathrm{C}$ both the ligands are of cyclic nature, so there is no possibility of these transitions.

3.3. ${ }^{1} H$ NMR Study. The ${ }^{1} \mathrm{H}$ NMR spectra of the complexes are consistent with the structures proposed in the reaction scheme. We find that bidentate ligands of synthesized complexes show a considerable downfield shift of protons after complexation with titanium. This shift may be due to transfer of electron density from ligand protons to the metal atom [35, 40]. However, protons of adamantylamine in all complexes appearing around $1.2-2.12 \mathrm{ppm}$ show a marginal chemical shift. The cyclic aliphatic nature of both the ligands in complex $\mathrm{C}$ creates complications in the spectrum as the peaks corresponding to these falls almost in the same region.

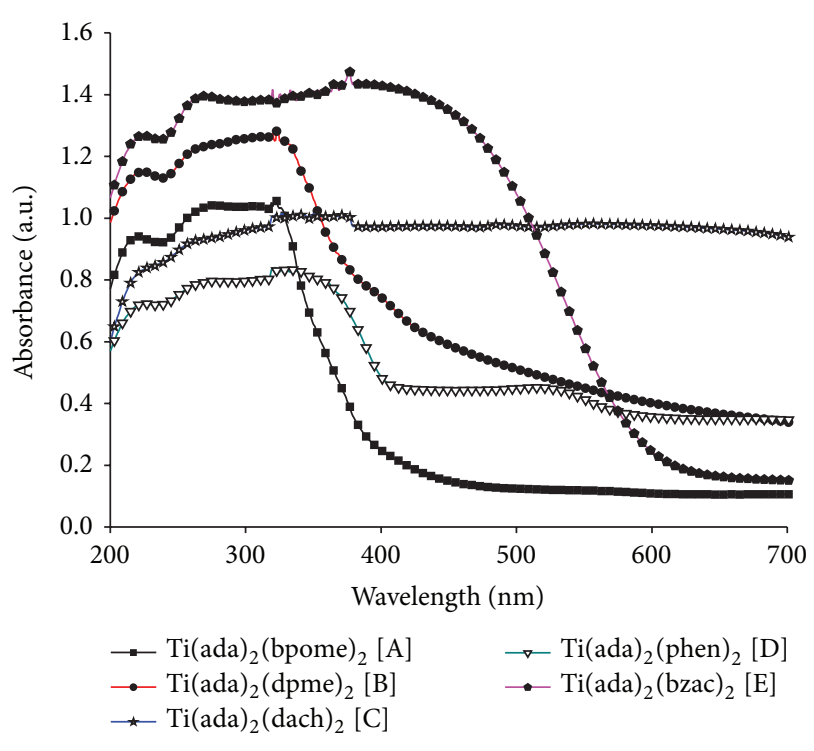

FIGURE 1: Electronic spectra of titanium complexes.

However, the integration of signals in all spectra supports the formation of proposed complexes.

3.4. Mass Spectra. The structure of complexes was further confirmed by recording electron spray mass spectrum. The complex A showed base peak at $m / z=152$ due to $\mathrm{C}_{10} \mathrm{H}_{17} \mathrm{~N}$ fragment ion and $4,4^{\prime}$-dimethoxy-2,2' -bipyridine ligand in the complex showed peak at $m / z=217$ with relative intensity of $25 \%$. We find that this complex also shows a peak at $\mathrm{m} / z$ $=478$ due to $\mathrm{TiC}_{24} \mathrm{H}_{24} \mathrm{~N}_{4} \mathrm{O}_{4}$ fragment ion. In case of complex $\mathrm{B}$, one peak at $m / z=185$ due to $\mathrm{C}_{12} \mathrm{H}_{12} \mathrm{~N}_{2}$ fragment ion and another peak at $m / z=152$ due to $\mathrm{C}_{10} \mathrm{H}_{17} \mathrm{~N}$ fragment ion were found with a relative intensity of $18 \%$. In complex $\mathrm{C}$, peaks were formed at $m / z=98,115,230$ due to $\mathrm{C}_{6} \mathrm{H}_{12} \mathrm{~N}, \mathrm{C}_{6} \mathrm{H}_{14} \mathrm{~N}_{2}$, and $\mathrm{TiC}_{10} \mathrm{H}_{19} \mathrm{~N}_{2}$ fragment ions. The complex $\mathrm{D}$ shows peaks at $m / z=304$ and 335 due to $\mathrm{TiC}_{16} \mathrm{H}_{22} \mathrm{~N}_{3}$ and $\mathrm{TiC}_{16} \mathrm{H}_{22} \mathrm{~N}_{3}$ fragment ions In addition to these peaks, complex $\mathrm{D}$ shows a molecular ion peak at $m / z=708$ with very low intensity. In complexes $\mathrm{C}, \mathrm{D}$, and $\mathrm{E}$, formation of the base peak takes place due to $\mathrm{C}_{10} \mathrm{H}_{17} \mathrm{~N}$ fragment ion at $m / z=152$. The complex E, in addition to base peak, also shows fragment ion peaks, in which one peak is formed at $\mathrm{m} / z=401$ due to $\mathrm{TiC}_{22} \mathrm{H}_{32} \mathrm{~N}_{2} \mathrm{O}_{2}$ fragment ion. The complexes $\mathrm{A}, \mathrm{B}, \mathrm{C}$, and $\mathrm{E}$ show their molecular ion peaks at $m / z=780,716,577$, and 670 
TABLE 2: Structure of ligands and proposed complexes.

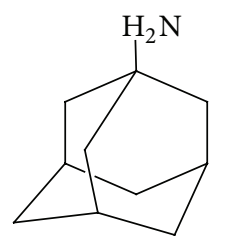

Adamantylamine

$\mathrm{H}_{3} \mathrm{CO}$<smiles>COc1ccnc(-c2cc(I)ccn2)c1</smiles>

$4,4^{\prime}$-Dimethoxy-2,2' -bipyridine

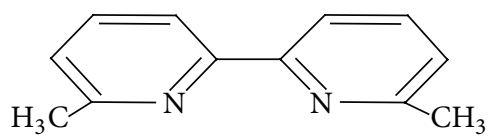

6,6 ${ }^{\prime}$-Dimethyl-2,2' -bipyridine

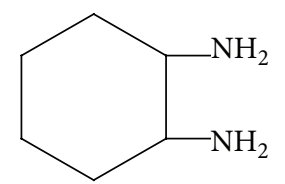

1,2-Diaminocyclohexane
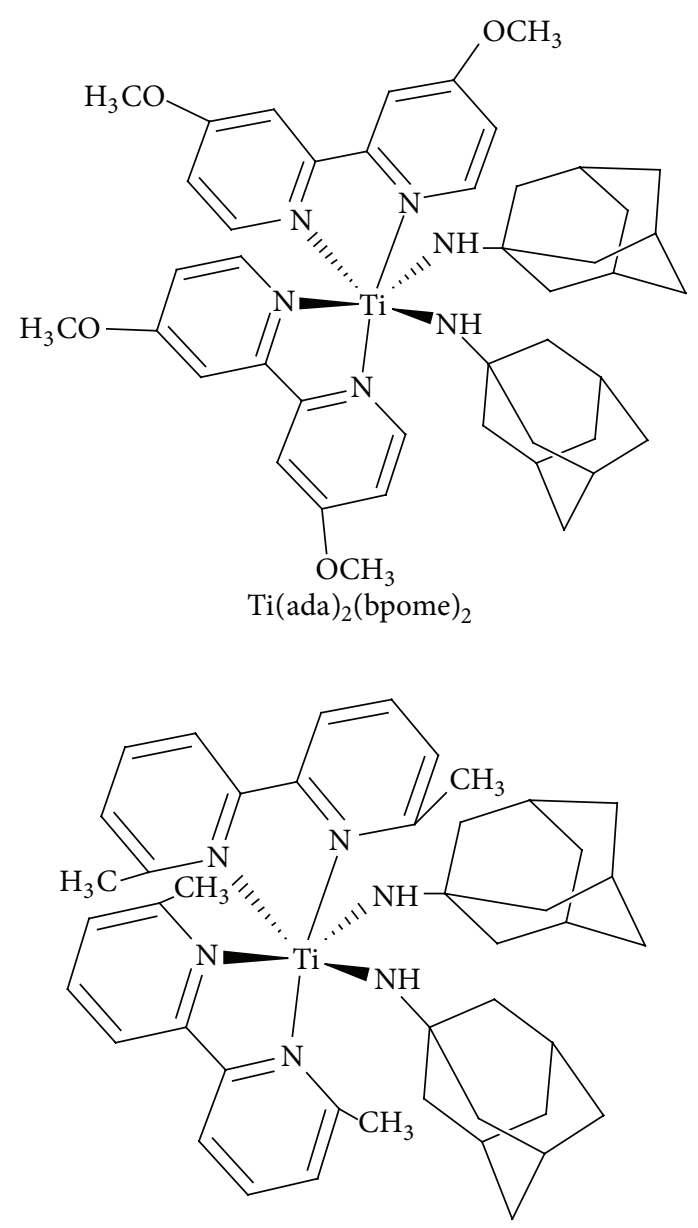

$\operatorname{Ti}(\text { ada })_{2}(\text { dpme })_{2}$

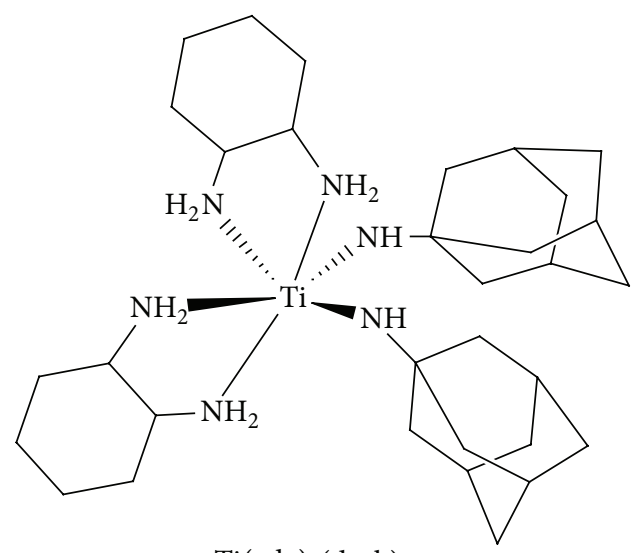

$\operatorname{Ti}(\text { ada })_{2}(\text { dach })_{2}$ 
TABle 2: Continued.

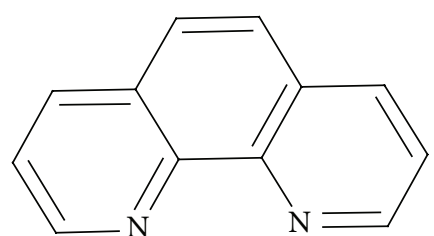

1,10-Phenanthroline

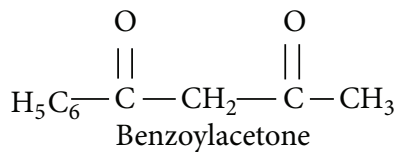

Benzoylacetone

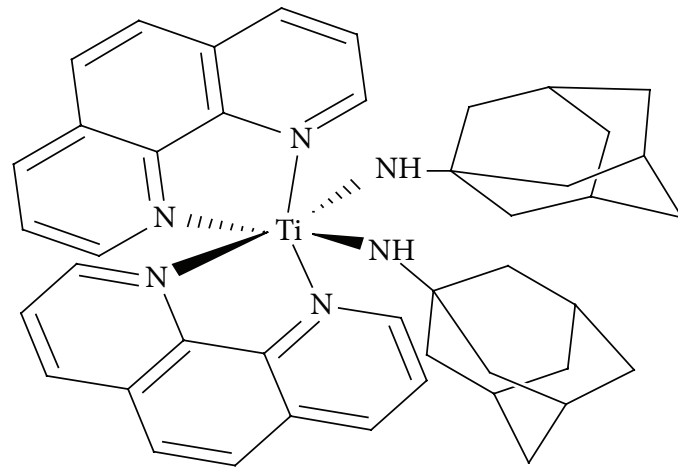

$\operatorname{Ti}(\text { ada })_{2}(\text { phen })_{2}$

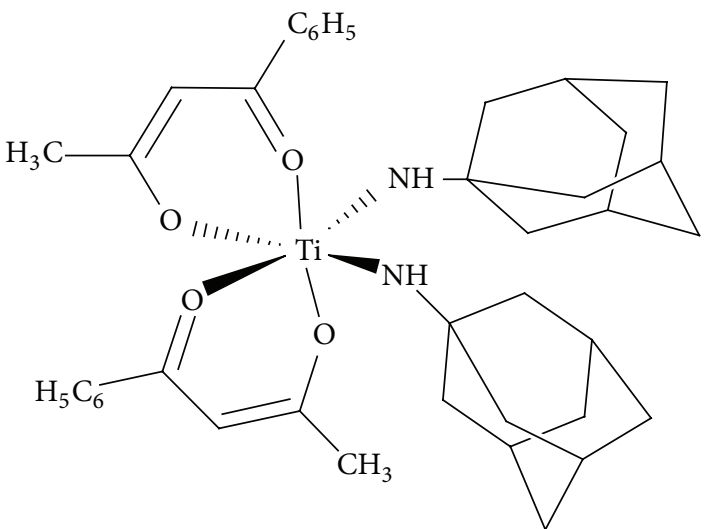

$\operatorname{Ti}(\text { ada })_{2}(\text { bzac })_{2}$

TABLE 3: Selected FTIR bands for titanium complexes and their corresponding ligands $\bar{\nu}\left(\mathrm{cm}^{-1}\right)$.

\begin{tabular}{|c|c|c|c|c|c|c|c|c|}
\hline Ligand/Complex & $\bar{\nu}_{\mathrm{Ti}-\mathrm{O}}$ & $\bar{\nu}_{\mathrm{Ti}-\mathrm{N}}$ & $\bar{\nu}_{\mathrm{C}-\mathrm{H}}$ bend & $\bar{\nu}_{\mathrm{C}-\mathrm{C} / \mathrm{C}=\mathrm{C}}$ stretch & $\bar{\nu}_{\mathrm{N}-\mathrm{H}}$ bend & $\bar{v}_{\mathrm{C}-\mathrm{H}}$ stretch & $\bar{\nu}_{\mathrm{N}-\mathrm{H}}$ stretch & $\bar{\nu}_{\mathrm{C}=\mathrm{O}}$ stretch \\
\hline Ada & - & - & 1132,1108 & 1457 & 1589 & 2912 & 3345,3372 & \\
\hline bpome & - & - & 1303,1230 & 1595 & - & 3071,2974 & - & \\
\hline $\mathrm{Ti}(\mathrm{ada})_{2}$ (bpome $)_{2}$ & - & 452 & 1313,1229 & 1629 & 1449 & 3015,2927 & 3388 & \\
\hline dpme & - & - & 1247,1158 & 1578 & - & 3063,2917 & - & \\
\hline $\operatorname{Ti}(\mathrm{ada})_{2}(\mathrm{dpme})_{2}$ & - & 404 & 1271,1117 & 1644 & 1441 & 3071,2925 & 3336 & \\
\hline dach & - & - & 1373,1072 & 1433 & 1578 & 2924 & 3357,3285 & \\
\hline $\operatorname{Ti}(\text { ada })_{2}(\text { dach })_{2}$ & - & 444 & 1360,1311 & 1470 & 1522 & 2925,2900 & 3379 & \\
\hline phen & - & - & 1344,1093 & 1603 & - & 3055 & - & \\
\hline $\operatorname{Ti}(\text { ada })_{2}(\text { phen })_{2}$ & - & 411 & 1368,1319 & 1612 & 1514 & 3039,2927 & 3412 & \\
\hline bzac & & & 1255 & 1409 & & 3063,3006 & & 1603 \\
\hline $\operatorname{Ti}(\mathrm{ada})_{2}(\mathrm{bzac})_{2}$ & 557 & 427 & 1109,1004 & 1522 & 1449 & 2933,2866 & 3379 & 1612 \\
\hline
\end{tabular}

indicating the formation of complexes. The existence of these different fragment ion peaks, base peaks, and molecular ion peaks supports the stoichiometric formulation of synthesized complexes [35].
3.5. Powder XRD Study. The powder X-ray diffraction study was performed to understand the lattice structure of the complexes. Figure 2 shows XRD pattern obtained for all the complexes with well-defined peaks in these patterns which 

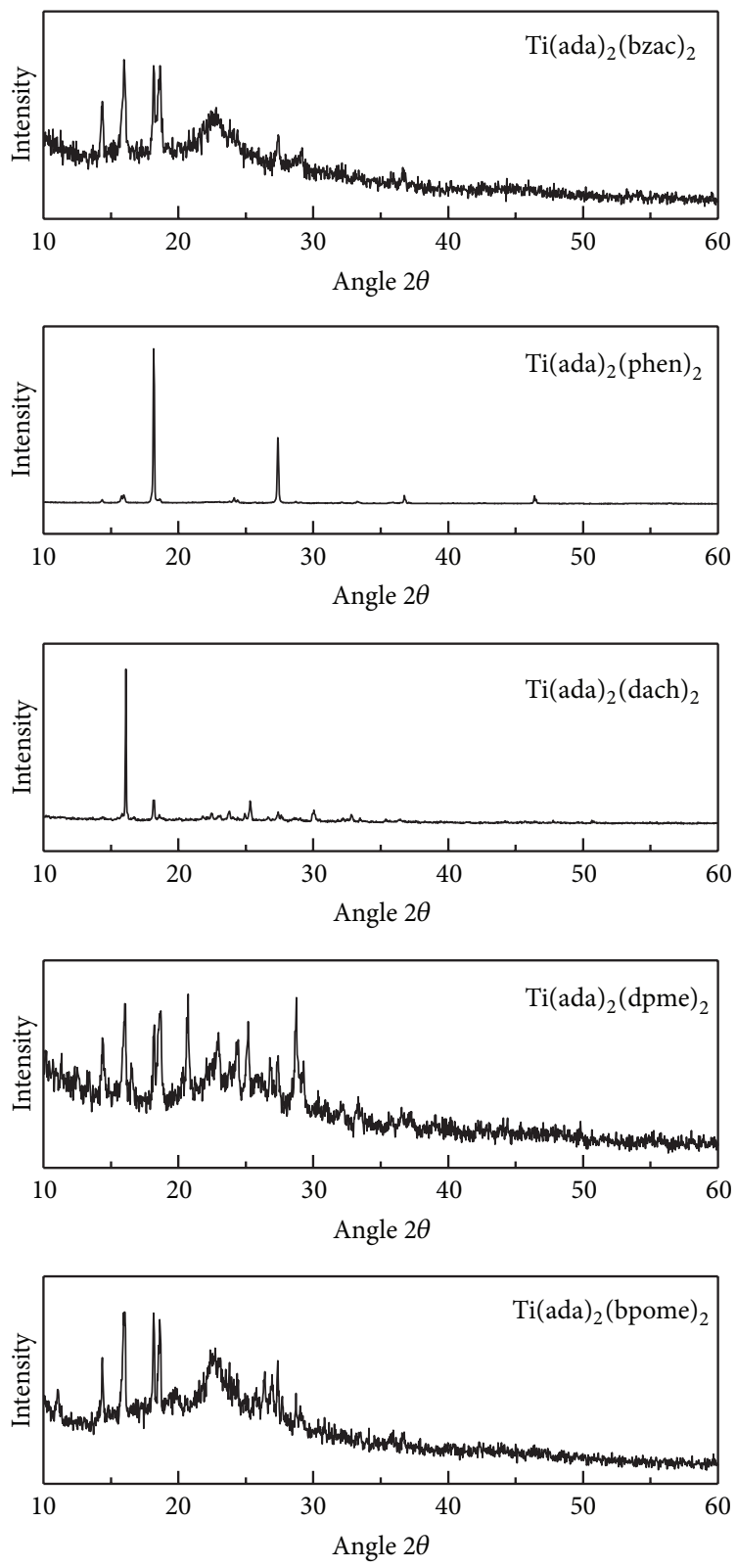

FIgURE 2: Powder XRD pattern of titanium complexes.

indicate the crystalline nature of complexes. Scherrer's equation $\mathrm{D}=(\lambda \times 0.9) /(\beta \times \operatorname{Cos} \theta)[35,41]$, with $\mathrm{D}$ as the crystallite size of (h kl) planes, $\lambda$ as the wavelength of incident radiation ( $\mathrm{CuK} \alpha, 1.54 \AA$ ), and $\beta$ as full width half maximum (FWHM), was used to calculate the crystallite size of complexes. The calculated crystallite size for complexes A, B, C, D, and E was $69,26.5,19.1,115$, and $76.6 \mathrm{~nm}$, respectively, which falls in nanorange. Unit cell parameter of the complexes has been calculated by using Powder X software [42] and the results are summarized in Table 4 . We have also observed that as the crystallite size decreases, peaks become broader as seen in Figure 2. On the basis of these different spectroscopic techniques, that is, UV-visible, FTIR, ${ }^{1} \mathrm{H}$ NMR, and mass spectrometry, an octahedral geometry may be proposed for the synthesized titanium complexes [43].
3.6. MTT Assay. The $\mathrm{IC}_{50}$ values were calculated by using best fit regression model and results have been tabulated in Table 5. The change in morphological features was observed at different concentrations of complexes, which indicates that such change in morphology is dose dependent as shown in Figure 3. The phase contrast imaging was done with a Nikon microscope at 40x after harvesting stage which clearly shows the formation of small apoptotic bodies, rounding of cells, shrinkage of cells, and plasma membrane blebbing. From the calculated $\mathrm{IC}_{50}$ values, it has been observed that complex $\mathrm{E}$ with benzoylacetone ligand shows $(4.06 \mu \mathrm{M})$ better activity than other complexes against the HeLa cell line, which is even better than known anticancer drug camptothecin as seen in Table 5. But ligands were found not much effective against the tested cancer cell lines. 
TABLE 4: XRD data of titanium complexes.

\begin{tabular}{|c|c|c|c|c|c|}
\hline Empirical formula & $\mathrm{TiC}_{44} \mathrm{H}_{54} \mathrm{~N}_{6} \mathrm{O}_{4}(\mathrm{~A})$ & $\mathrm{TiC}_{44} \mathrm{H}_{54} \mathrm{~N}_{6}(\mathrm{~B})$ & $\mathrm{TiC}_{32} \mathrm{H}_{58} \mathrm{~N}_{6}(\mathrm{C})$ & $\mathrm{TiC}_{44} \mathrm{H}_{46} \mathrm{~N}_{6}(\mathrm{D})$ & $\mathrm{TiC}_{40} \mathrm{H}_{48} \mathrm{~N}_{2} \mathrm{O}_{2}(\mathrm{E})$ \\
\hline Formula weight & 780 & 716 & 576 & 708 & 670 \\
\hline Crystal system & Monoclinic & Monoclinic & Monoclinic & Monoclinic & Monoclinic \\
\hline Lattice type & $\mathrm{P}$ & $\mathrm{P}$ & $\mathrm{P}$ & $\mathrm{P}$ & $\mathrm{P}$ \\
\hline$a\left(\mathrm{~A}^{\circ}\right)$ & 17 & 13 & 16 & 11 & 17 \\
\hline$b\left(\mathrm{~A}^{\circ}\right)$ & 13 & 11 & 12 & 13 & 11 \\
\hline$c\left(\mathrm{~A}^{\circ}\right)$ & 14 & 20 & 15 & 14 & 16 \\
\hline$\alpha\left({ }^{\circ}\right)$ & 90 & 90 & 90 & 90 & 90 \\
\hline$\beta\left(^{\circ}\right)$ & 91 & 106 & 113 & 106 & 85 \\
\hline$\gamma\left({ }^{\circ}\right)$ & 90 & 90 & 90 & 90 & 90 \\
\hline Crystallite size $(\mathrm{nm})$ & 69 & 26.5 & 19.1 & 115 & 76.6 \\
\hline$V\left(\mathrm{~A}^{\circ}\right)^{3}$ & 3094 & 2860 & 2880 & 2002 & 2992 \\
\hline $2 \theta$ start & 10 & 10 & 10 & 10 & 10 \\
\hline $2 \theta$ end & 60 & 60 & 60 & 60 & 60 \\
\hline Radiation & $\mathrm{Cu}$ & $\mathrm{Cu}$ & $\mathrm{Cu}$ & $\mathrm{Cu}$ & $\mathrm{Cu}$ \\
\hline Wavelength & 1.54 & 1.54 & 1.54 & 1.54 & 1.54 \\
\hline
\end{tabular}

TABLE 5: Cytotoxic studies of titanium complexes on HeLa, C6 and CHO cancer cell lines as determined by MTT assay.

\begin{tabular}{|c|c|c|c|}
\hline \multirow[b]{2}{*}{ Complex } & \multicolumn{3}{|c|}{ Cell line (Source) } \\
\hline & Hela (cervical) & $\begin{array}{c}\text { C6 (Rat glioma) } \\
\mathrm{IC}_{50}(\mu \mathrm{M})\end{array}$ & $\mathrm{CHO}$ (Ovary) \\
\hline $\mathrm{Ti}(\mathrm{ada})_{2}(\mathrm{bpome})_{2}$ & 13 & 17.8 & 19.9 \\
\hline $\operatorname{Ti}(\mathrm{ada})_{2}(\mathrm{dpme})_{2}$ & 74 & 69.8 & 16.1 \\
\hline $\operatorname{Ti}(\text { ada })_{2}(\text { dach })_{2}$ & 20.4 & 21 & 16.6 \\
\hline $\operatorname{Ti}(\text { ada })_{2}(\text { phen })_{2}$ & 11.1 & 22.1 & 21.5 \\
\hline $\operatorname{Ti}(\text { ada })_{2}(\mathrm{bzac})_{2}$ & 4.06 & 21.8 & 46.1 \\
\hline Adamantylamine & 104.5 & 148 & 123 \\
\hline Camptothecin & 6.2 & 6.4 & 6.4 \\
\hline
\end{tabular}

The $\mathrm{IC}_{50}$ values of main ligand, that is, adamantylamine along with its complexes, has been shown in Table 5 . Complexes A, C, and D with $4,4^{\prime}$-dimethoxy-2,2' - bipyridine, 1,2 diaminocyclohexane, and 1,10-phenanthroline ligand shows good activity against all the tested cell lines which may be due to the presence of electron withdrawing nature of methoxy group, cyclic nature of 1,2-diaminocyclohexane, and aromatic nature of 1,10-phenanthroline ligand. However, complex $\mathrm{B}$ with $6,6^{\prime}$-dimethyl-2,2' -bipyridine was not found much effective against HeLa and C6 cell lines, which may be due to the presence of electron donating methyl groups in the ligand. So, it could be summarized that electron withdrawing group present in ligand as well as cyclic and aromatic nature of ligand are responsible for the cytotoxicity of titanium complexes.

3.7. Cell Cycle Analysis Using Propidium Iodide. For cell cycle analysis, $\mathrm{CHO}$ cells were treated with the complexes at three concentrations almost near to their $\mathrm{IC}_{50}$ values which caused the decrease in the number of cells with an increase in dose due to induction of apoptosis. It has been observed that all complexes increases cells in hypo-diploid cells of cell cycle and also increased the cell death with increase in concentration. Among all the complexes, complex E having benzoylacetone ligand showed $44.3 \%$ cell death at $80 \mu \mathrm{M}$, which is the maximum for all the complexes. However, known anticancer drug Camptothecin showed $45.5 \%$ cell death at $6 \mu \mathrm{M}$. Abundant evidences suggest that mitochondria plays a key role in the initiation of apoptosis by releasing Cytochrome C $[44,45]$. In addition to Cytochrome C, other factors such as apoptosis signaling molecules and apoptosis inducing factor (AIF) can be important triggers of apoptosis [18]. It has been confirmed from cell cycle analysis (Figure 4) that cell death occurred through increase in hypo-diploid cells (Sub-G $G_{1}$ population) which indicates apoptosis. Previous studies showed that titanium affects polymerase proteins and transcription factors which inhibits protein synthesis and causes cytotoxicity [46].

\section{Conclusions}

We have reported the synthesis of mixed ligand titanium complexes having nitrogen containing ligands. The structure of the complexes has been confirmed by elemental analysis, 

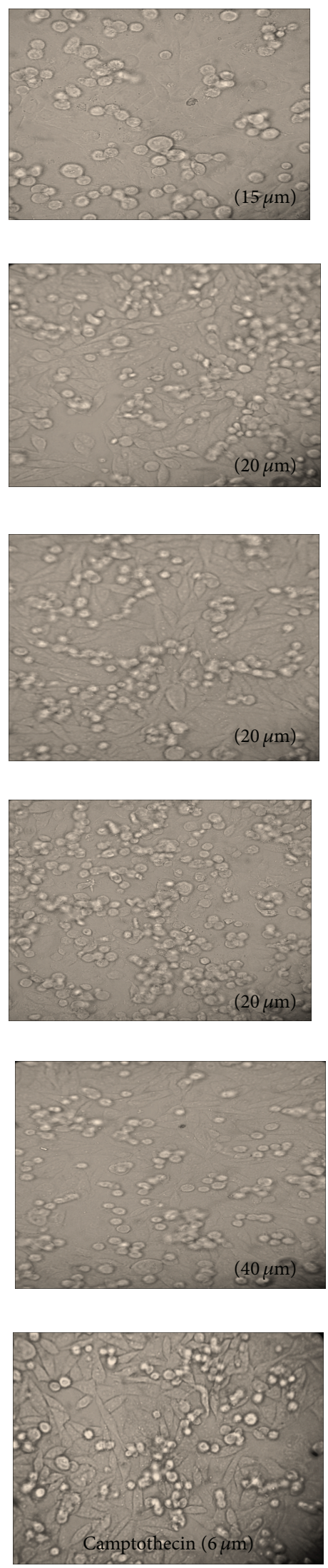

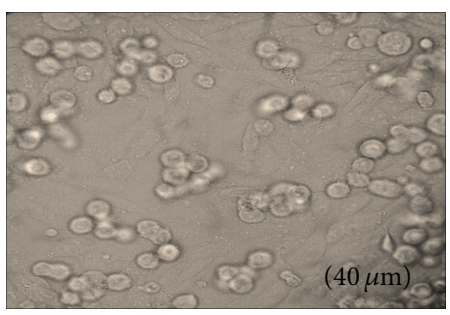

(A)
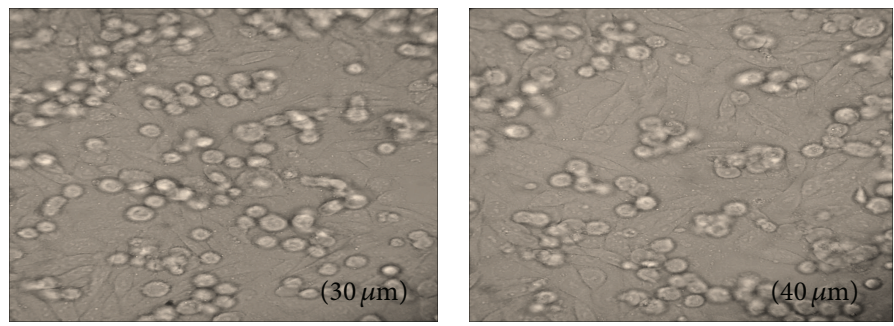

(B)
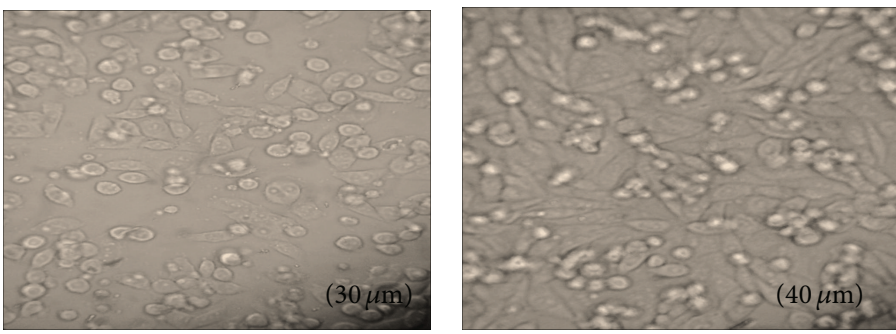

(C)
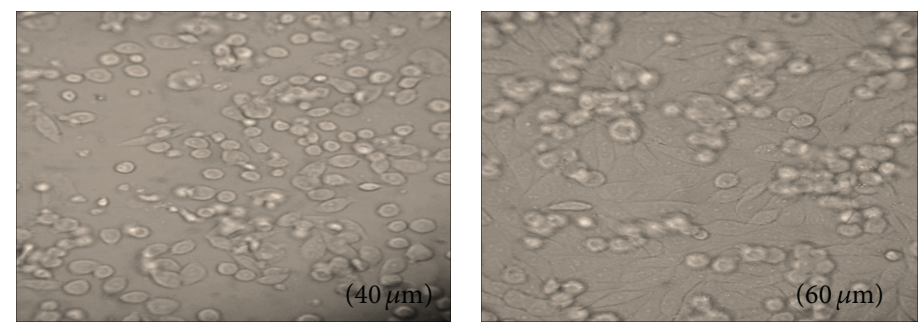

(D)
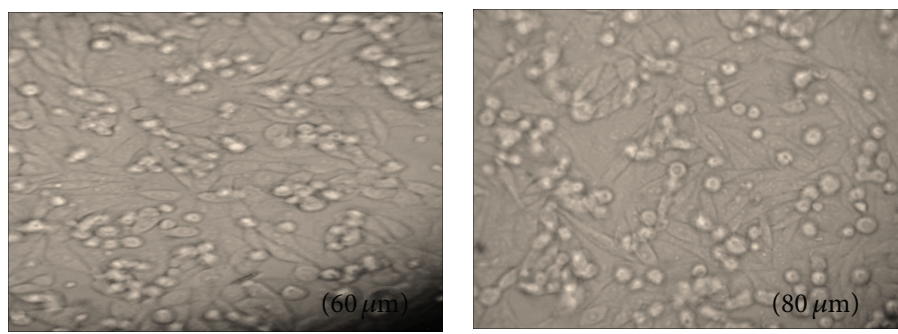

(E)

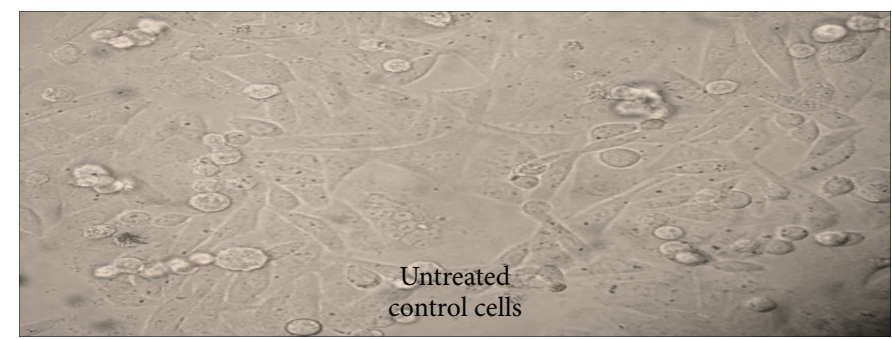

FIGURE 3: Morphology of CHO cells at different concentrations of titanium complexes. 


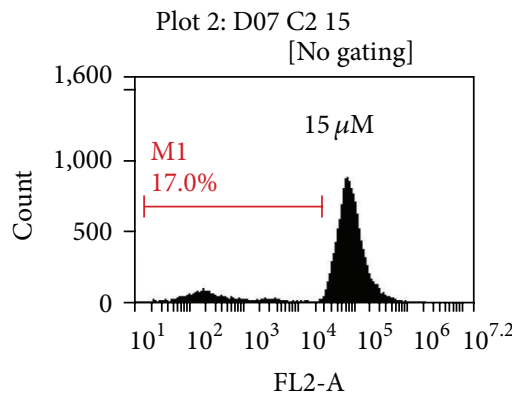

Plot 2: G07 D2 20

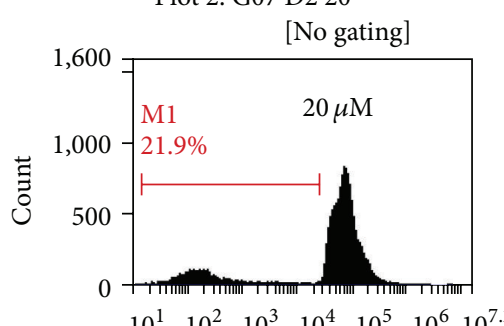

$\begin{array}{lllllll}10^{1} & 10^{2} & 10^{3} & 10^{4} & 10^{5} & 10^{6} & 10^{7.2}\end{array}$

FL2-A

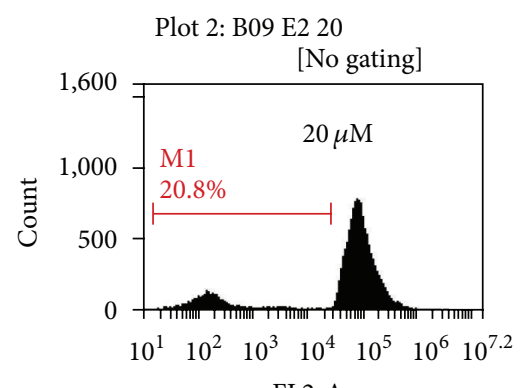

FL2-A

Plot 2: E09 F2 20

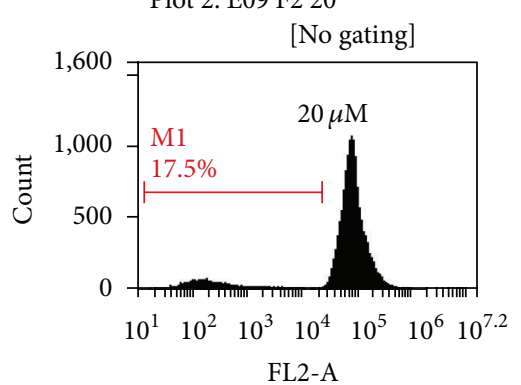

Plot 2: H09 G2 40

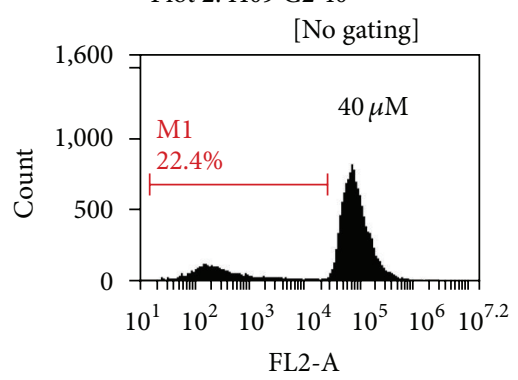

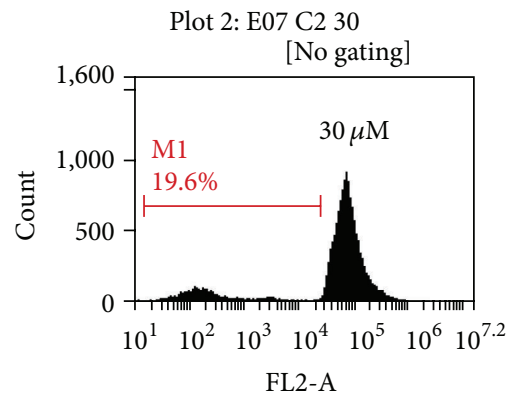

(A)

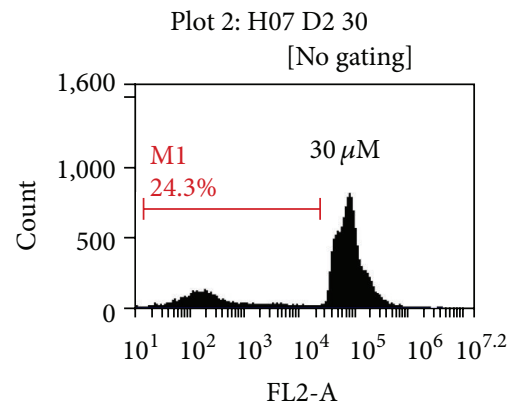

(B)

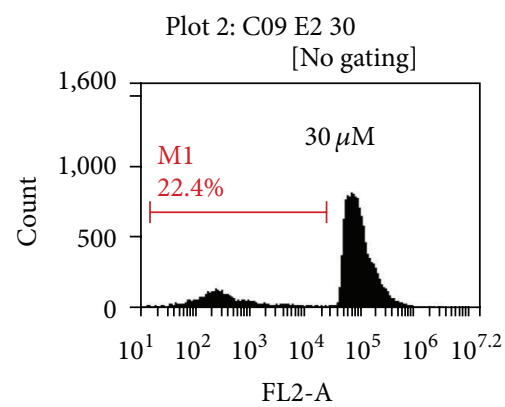

(C)

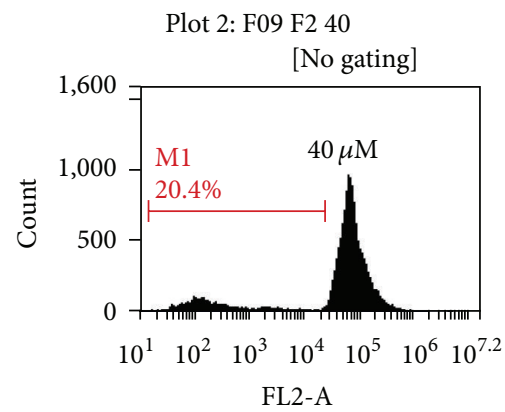

(D)

Plot 2: B11 G2 60

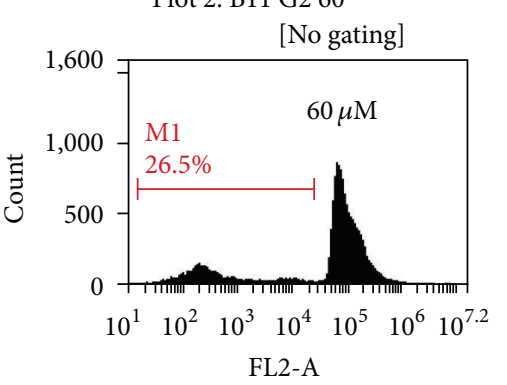

(E)

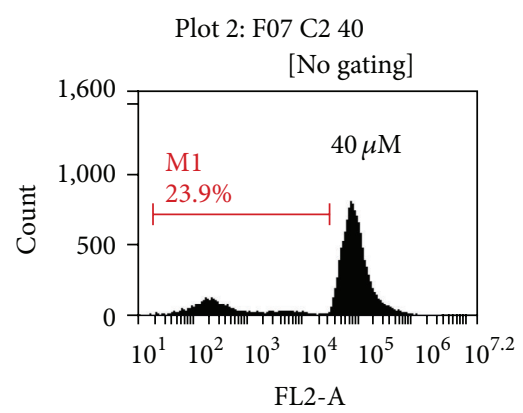

Plot 2: A09 D2 40
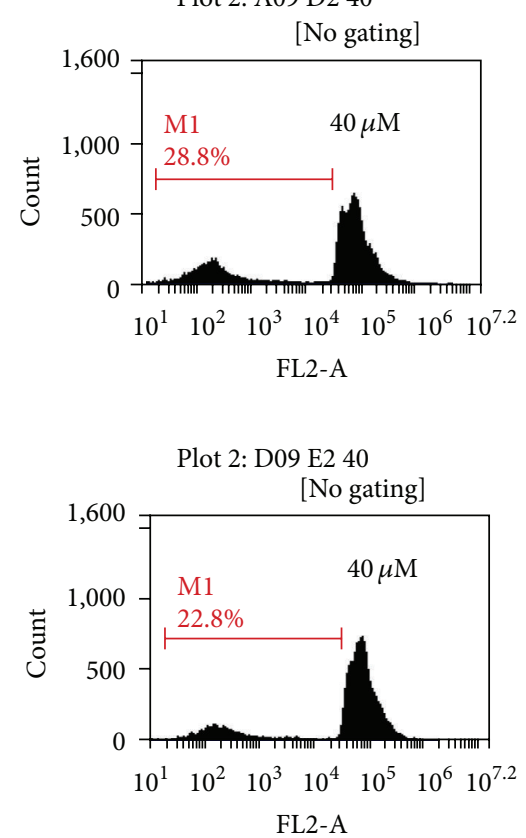

Plot 2: G09 F2 60

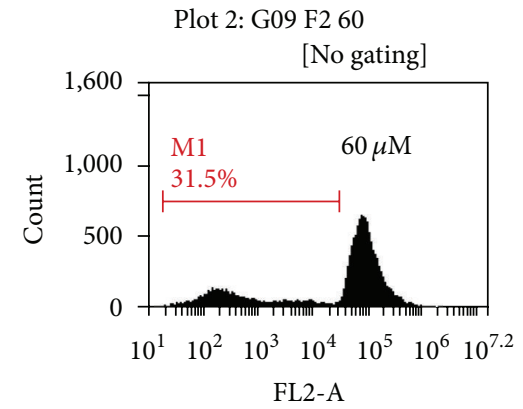

Plot 2: A11 G2 80

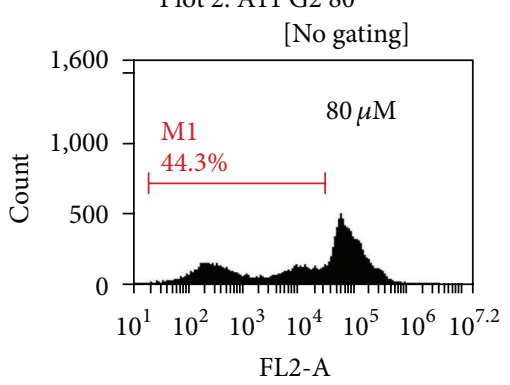

Figure 4: Continued. 

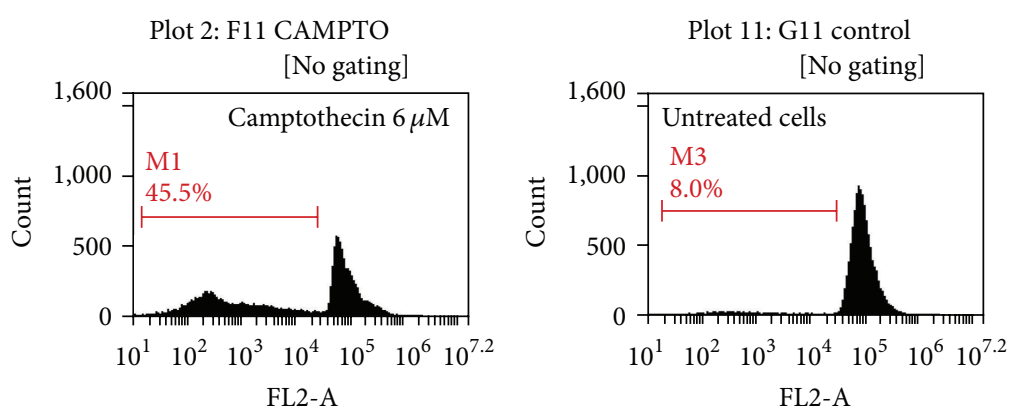

FIGURE 4: Cell cycle analysis of CHO cells exposed to different concentrations of titanium complexes that is, below IC50, near IC50, and above IC50 on flow cytometer by staining with propidium iodide.

FTIR, UV-visible, ${ }^{1} \mathrm{H}$ NMR, and mass spectrometry techniques. Cytotoxic studies were done on different cell lines and it has been found that complex E with benzoylacetone ligand was a more potent cytotoxic agent. The morphological analysis on CHO cells indicates characteristics features of apoptosis and cell cycle analysis indicate increase in hypo-diploid cells. The mechanism of action has been certainly established in vitro; however, the efficacy of these complexes with their action mechanisms should also be demonstrated in vivo.

\section{Conflict of Interests}

The authors declare that there is no conflict of interests regarding the publication of this paper.

\section{Acknowledgments}

The authors would like to thank Director of National Institute of Technology, Hamirpur, India, for providing necessary laboratory facilities to carry out this work. The authors also acknowledge Head of Department of Botanical and Environmental Sciences, Guru Nanak Dev University, Amritsar, Punjab, India, for providing the necessary facilities for in vitro analysis.

\section{References}

[1] E. Wiltshaw, "Cisplatin in the treatment of cancer," Platinum Metals Review, vol. 23, no. 3, pp. 90-98, 1979.

[2] J. Reedijk, "Why does cisplatin reach guanine-N7 with competing S-donor ligands available in the cell?" Chemical Reviews, vol. 99, no. 9, pp. 2499-2510, 1999.

[3] I. Kostova, "Platinum complexes as anticancer agents," Recent Patents on Anti-Cancer Drug Discovery, vol. 1, no. 1, pp. 1-22, 2006.

[4] S. Fruhauf and W. J. Zeller, "New platinum, titanium, and ruthenium complexes with different patterns of DNA damage in rat ovarian tumor cells," Cancer Research, vol. 51, no. 11, pp. 29432948, 1991.

[5] A. Bergamo, A. Masi, M. A. Jakupec, B. K. Keppler, and G. Sava, "Inhibitory effects of the ruthenium complex KP1019 in models of mammary cancer cell migration and invasion," Metal-Based Drugs, vol. 2009, Article ID 681270, 9 pages, 2009.
[6] M. J. Clarke, "Ruthenium in cancer chemotherapy," Platinum Metals Review, vol. 32, no. 4, pp. 198-199, 1988.

[7] S. S. Anchuri, S. Thota, R. Yerra, and S. Dhulipala, "In vitro antioxidant activity of some novel synthetic mononuclear ruthenium (II) compounds," Letters in Drug Design and Discovery, vol. 9, no. 4, pp. 421-425, 2012.

[8] M. Auzias, B. Therrien, G. Süss-Fink, P. Štěpnička, H. A. Wee, and P. J. Dyson, "Ferrocenoyl pyridine arene ruthenium complexes with anticancer properties: synthesis, structure, electrochemistry, and cytotoxicity," Inorganic Chemistry, vol. 47, no. 2, pp. 578-583, 2008.

[9] J. -Y. Kim, "Synthesis of some Palladium(II) complexes of 1,2Diamino cyclohexane and dicarboxylates as cis-platin analogues of palladium series," Archives of Pharmacal Research, vol. 15 , no. 4, pp. 336-342, 1992.

[10] A. S. Abu-Surrah, H. H. Al-Sa'doni, and M. Y. Abdalla, "Palladium based chemotherapeutic agents. Routes towards complexes with good antitumor activity," Cancer Therapy, vol. 6, pp. 1-10, 2008.

[11] M. Islami-Moghaddam, H. Mansouri-Torshizi, A. Divsalar, and A. A. Saboury, "Synthesis, characterization, cytotoxic and DNA binding studies of diimine platinum(II) and palladium(II) complexes of short hydrocarbon chain ethyldithiocarbamate ligand," Journal of the Iranian Chemical Society, vol. 6, no. 3, pp. 552-569, 2009.

[12] P. Chellan, N. Shunmoogam-Gounden, D. T. Hendricks et al., "Synthesis, structure and in vitro biological screening of palladium(II) complexes of functionalised salicylaldimine thiosemicarbazones as antimalarial and anticancer agents," European Journal of Inorganic Chemistry, no. 22, pp. 3520-3528, 2010.

[13] A. Srivastava and D. C. Gupta, "Synthesis and structural investigations of coordination compounds of palladium(II) with 5-methyl uracil," International Journal of Applied Engineering Research, Dindigul, vol. 1, no. 2, pp. 222-227, 2010.

[14] C. Gabbiani, A. Casini, and L. Messori, "Gold(III) compounds as anticancer drugs," Gold Bulletin, vol. 40, no. 1, pp. 73-81, 2007.

[15] A. Casini, M. C. Diawara, R. Scopelliti, S. M. Zakeeruddin, M. Grätzel, and P. J. Dyson, "Synthesis, characterisation and biological properties of gold(iii) compounds with modified bipyridine and bipyridylamine ligands," Dalton Transactions, vol. 39, no. 9, pp. 2239-2245, 2010.

[16] E. Meléndez, "Titanium complexes in cancer treatment," Critical Reviews in Oncology/Hematology, vol. 42, no. 3, pp. 309-315, 2002.

[17] E. Dubler, R. Buschmann, and H. W. Schmalle, "Isomer abundance of bis( $\beta$-diketonato) complexes of titanium(IV). 
Crystal structures of the antitumor compound budotitane $\left[\mathrm{Ti}^{\mathrm{IV}}(\mathrm{bzac})_{2}(\mathrm{OEt})_{2}\right]$ and of its dichloro-derivative $\left[\mathrm{Ti}^{\mathrm{IV}}(\mathrm{bzac})_{2} \mathrm{Cl}_{2}\right]$ (bzac = 1-phenylbutane-1,3-dionate)," Journal of Inorganic Biochemistry, vol. 95, no. 2-3, pp. 97-104, 2003.

[18] K. O'Connor, C. Gill, M. Tacke et al., "Novel titanocene anticancer drugs and their effect on apoptosis and the apoptotic pathway in prostate cancer cells," Apoptosis, vol. 11, no. 7, pp. 1205-1214, 2006.

[19] C. Pampillón, J. Claffey, M. Hogan, and M. Tacke, "Novel achiral titanocene anti-cancer drugs synthesised from bis-N,Ndimethylamino fulvene and lithiated heterocyclic compounds," BioMetals, vol. 21, no. 2, pp. 197-204, 2008.

[20] S. Eger, T. A. Immel, J. Claffey et al., "Titanocene difluorides with improved cytotoxic activity," Inorganic Chemistry, vol. 49, no. 4, pp. 1292-1294, 2010.

[21] L. M. Gao and E. Meléndez, "Cytotoxic properties of titanocenyl amides on breast cancer cell line MCF-7," Metal-Based Drugs, vol. 2010, Article ID 286298, 6 pages, 2010.

[22] E. A. Williamson, T. J. Boyle, R. Raymond et al., "Cytotoxic activity of the titanium alkoxide $(\mathrm{OPy})_{2} \mathrm{Ti}(4 \mathrm{AP})_{2}$ against cancer colony forming cells," Investigational New Drugs, vol. 30, no. 1, pp. 114-120, 2012.

[23] M. Tacke, L. T. Allen, L. Cuffe et al., "Novel titanocene anticancer drugs derived from fulvenes and titanium dichloride," Journal of Organometallic Chemistry, vol. 689, no. 13, pp. 22422249, 2004.

[24] M. Hogan, J. Claffey, E. Fitzpatrick, T. Hickey, C. Pampillon, and M. Tacked, "Synthesis and cytotoxicity studies of titanocene C analogues," Metal-Based Drugs, vol. 2008, Article ID 754358, 7 pages, 2008.

[25] F.-J. K. Rehmann, A. J. Rous, O. Mendoza et al., “A trimethoxyphenyl substituted ansa-titanocene: a possible anticancer drug," Polyhedron, vol. 24, no. 11, pp. 1250-1255, 2005.

[26] G. Sava and A. Bergamo, "Ruthenium-based compounds and tumour growth control (review)," International Journal of Oncology, vol. 17, no. 2, pp. 353-365, 2000.

[27] J. M. Rademaker-Lakhai, D. Van Den Bongard, D. Pluim, J. H. Beijnen, and J. H. M. Schellens, "A phase I and pharmacological study with imidazolium-trans-DMSO-imidazoletetrachlororuthenate, a novel ruthenium anticancer agent," Clinical Cancer Research, vol. 10, no. 11, pp. 3717-3727, 2004.

[28] G. Sava, R. Gagliardi, A. Bergamo, E. Alessio, and G. Mestroni, "Treatment of metastases of solid mouse tumours by NAMIA: comparison with cisplatin, cyclophosphamide and dacarbazine," Anticancer Research, vol. 19, no. 2A, pp. 969-972, 1999.

[29] A. Bergamo, B. Gava, E. Alessio et al., "Ruthenium-based NAMI-A type complexes with in vivo selective metastasis reduction and in vitro invasion inhibition unrelated to cell cytotoxicity," International Journal of Oncology, vol. 21, no. 6, pp. 1331-1338, 2002.

[30] M. Shavit, D. Peri, A. Melman, and E. Y. Tshuva, "Antitumor reactivity of non-metallocene titanium complexes of oxygenbased ligands: is ligand lability essential?" Journal of Biological Inorganic Chemistry, vol. 12, no. 6, pp. 825-830, 2007.

[31] A. D. Tinoco, H. R. Thomas, C. D. Incarvito, A. Saghatelian, and A. M. Valentine, "Cytotoxicity of a $\mathrm{Ti}(\mathrm{IV})$ compound is independent of serum proteins," Proceedings of the National Academy of Sciences of the United States of America, vol. 109, no. 13, pp. 5016-5021, 2012.
[32] S. Halder, S.-M. Peng, G.-H. Lee et al., "Synthesis, structure, spectroscopic properties and cytotoxic effect of some thiosemicarbazone complexes of palladium," New Journal of Chemistry, vol. 32, no. 1, pp. 105-114, 2008.

[33] D. Kovala-Demertzi, M. A. Demertzis, J. R. Miller, C. Papadopoulou, C. Dodorou, and G. Filousis, "Platinum(II) complexes with 2-acetyl pyridine thiosemicarbazone: synthesis, crystal structure, spectral properties, antimicrobial and antitumour activity," Journal of Inorganic Biochemistry, vol. 86, no. 2-3, pp. 555-563, 2001.

[34] T. Mosmann, "Rapid colorimetric assay for cellular growth and survival: application to proliferation and cytotoxicity assays," Journal of Immunological Methods, vol. 65, no. 1-2, pp. 55-63, 1983.

[35] R. Kaushal, N. Kumar, P. Awasthi, and K. Nehra, "Syntheses, characterization and antibacterial study of titanium complexes," Turkish Journal of Chemistry, vol. 37, no. 6, pp. 936-945, 2013.

[36] X.-M. Shi, H.-Y. Wang, Y.-B. Li et al., "Spectroscopic studies on $\mathrm{Co}(\mathrm{II}), \mathrm{Ni}(\mathrm{II}), \mathrm{Zn}(\mathrm{II})$ complexes with $4,4^{\prime}$ - bipyridine," Chemical Research in Chinese Universities, vol. 26, no. 6, pp. 1011-1015, 2010.

[37] D. M. Czakis-Sulikowska, J. Radwańska-Doczekalska, and G. Sójka, "4,4'-Dipyridyl complexes of rare-earth thiocyanates," Monatshefte für Chemie Chemical Monthly, vol. 115, no. 8-9, pp. 961-973, 1984.

[38] M. Gülcan, M. Sönmez, and I. Berber, "Synthesis, characterization, and antimicrobial activity of a new pyrimidine Schiff base and its $\mathrm{Cu}(\mathrm{II}), \mathrm{Ni}(\mathrm{II}), \mathrm{Co}(\mathrm{II}), \mathrm{Pt}(\mathrm{II})$, and Pd(II) complexes," Turkish Journal of Chemistry, vol. 36, no. 1, pp. 189-200, 2012.

[39] S. Xiao, H. Lu, and M. Zhang, "Studies on $\mathrm{TiCl}_{4} / \mathrm{Mg}(\mathrm{OEt})_{2} / \mathrm{EB}$ supported catalysts for propylene polymerization," Chinese Journal of Polymer Science, vol. 8, no. 3, pp. 253-260, 1990.

[40] K. Zamani, A. Mobinikhaledi, N. Foroughifar, K. Faghihi, and V. Mahdavi, "H NMR studies of some imidazole ligands coordinated to Co(III)," Turkish Journal of Chemistry, vol. 27, no. 1, pp. 71-75, 2003.

[41] C. J. Dhanaraj and M. S. Nair, "Synthesis and characterization of metal(II) complexes of poly(3-nitrobenzylidene1-naphthylamine-co-succinic anhydride)," European Polymer Journal, vol. 45, no. 2, pp. 565-572, 2009.

[42] S. B. Ade, M. N. Deshpande, and D. G. Kolhatkar, "Synthesis, characterization, spectroscopic studies and antimicrobial activity of 2-[(2-Hydroxy-5-nitrobenzylidene)-amino]-4methyl-phenol with complexes of Cd(II) and $\mathrm{Hg}(\mathrm{II})$ ions," International Journal of ChemTech Research, vol. 4, no. 2, pp. 474478, 2012.

[43] N. P. Priya, S. V. Arunachalam, N. Sathya, V. Chinnusamy, and C. Jayabalakrishnan, "Catalytic and antimicrobial studies of binuclear ruthenium(III) complexes containing bis- $\beta$ diketones," Transition Metal Chemistry, vol. 34, no. 4, pp. 437445, 2009.

[44] J. M. Penninger and G. Kroemer, "Mitochondria, AIF and caspases-rivaling for cell death execution," Nature Cell Biology, vol. 5, no. 2, pp. 97-99, 2003.

[45] L. Ravagnan, T. Roumier, and G. Kroemer, "Mitochondria, the killer organelles and their weapons," Journal of Cellular Physiology, vol. 192, no. 2, pp. 131-137, 2002.

[46] C. V. Christodoulou, A. G. Eliopoulos, L. S. Young, L. Hodgkins, D. R. Ferry, and D. J. Kerr, "Anti-proliferative activity and mechanism of action of titanocene dichloride," British Journal of Cancer, vol. 77, no. 12, pp. 2088-2097, 1998. 

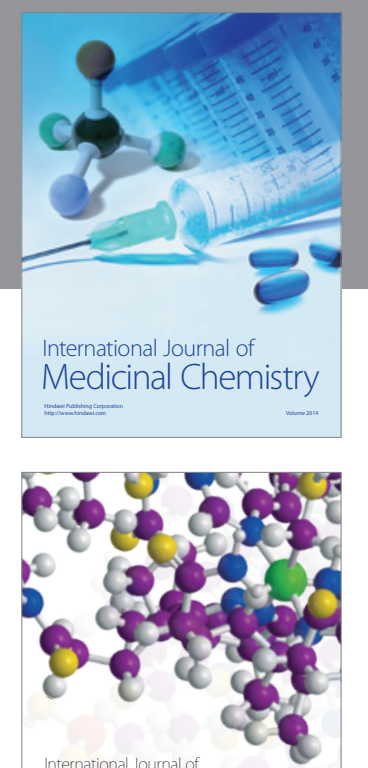

\section{Carbohydrate} Chemistry

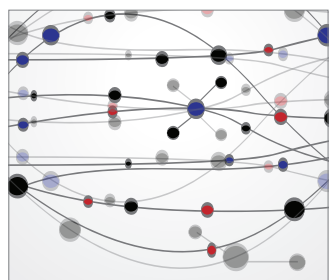

The Scientific World Journal
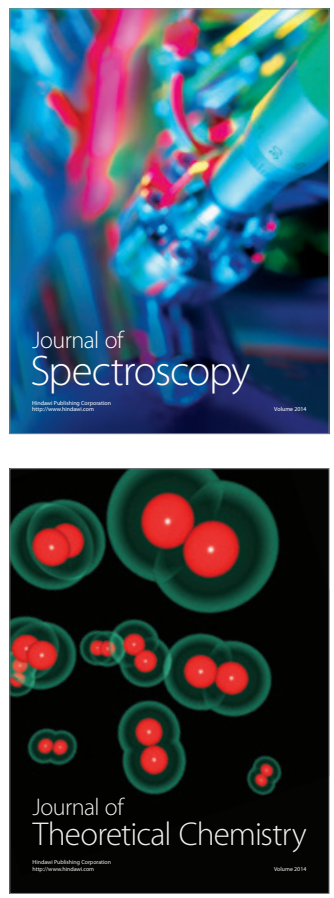
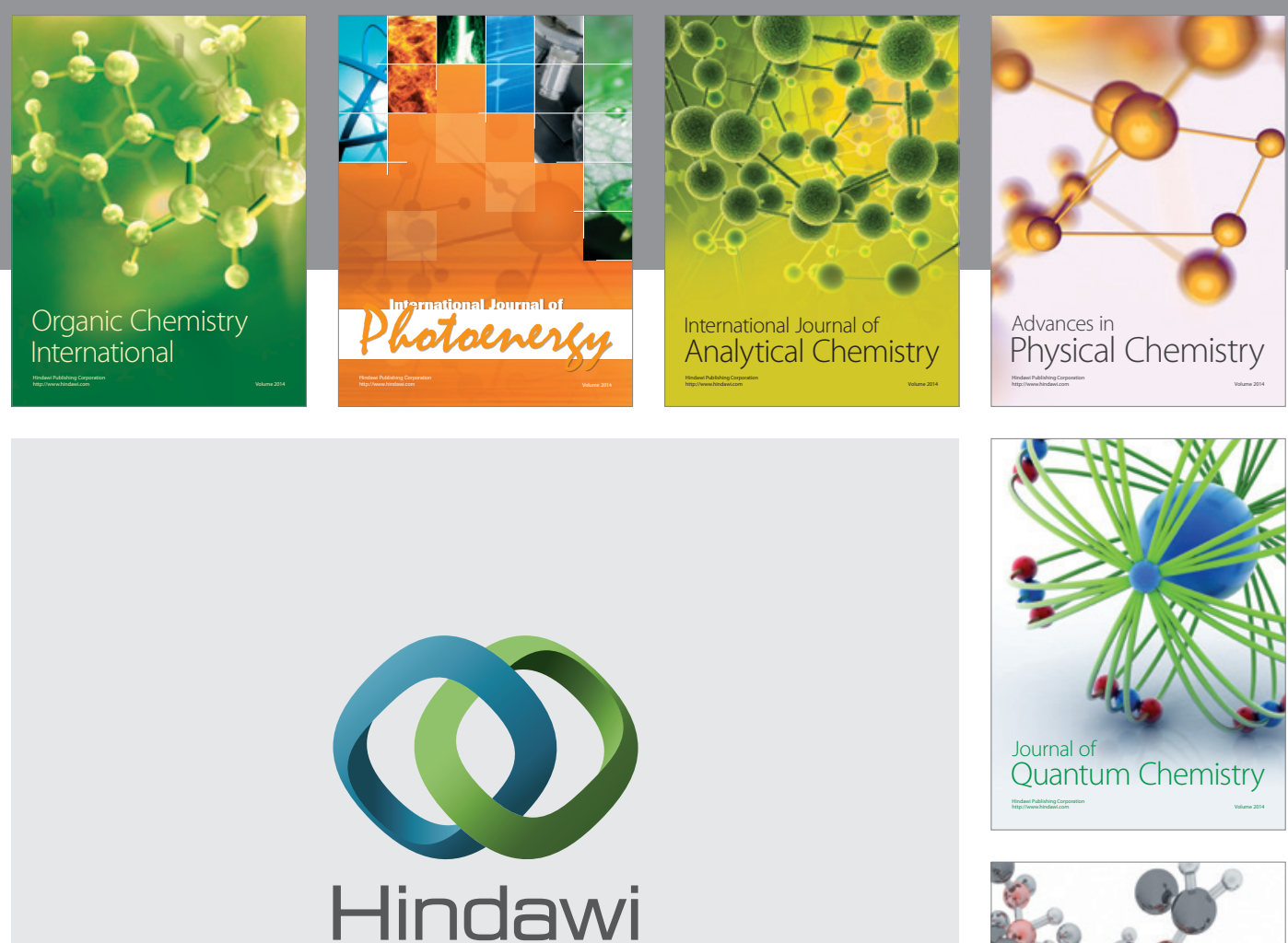

Submit your manuscripts at

http://www.hindawi.com

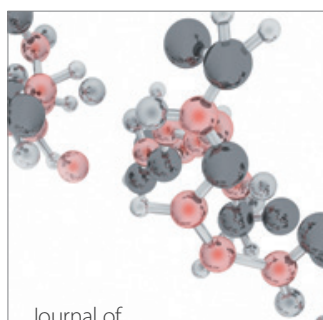

Analytical Methods

in Chemistry

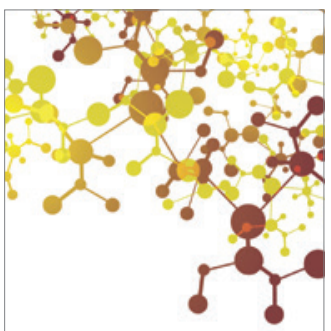

Journal of

Applied Chemistry

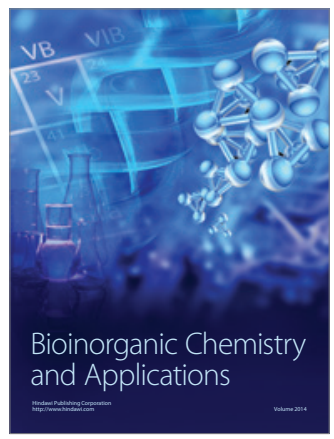

Inorganic Chemistry
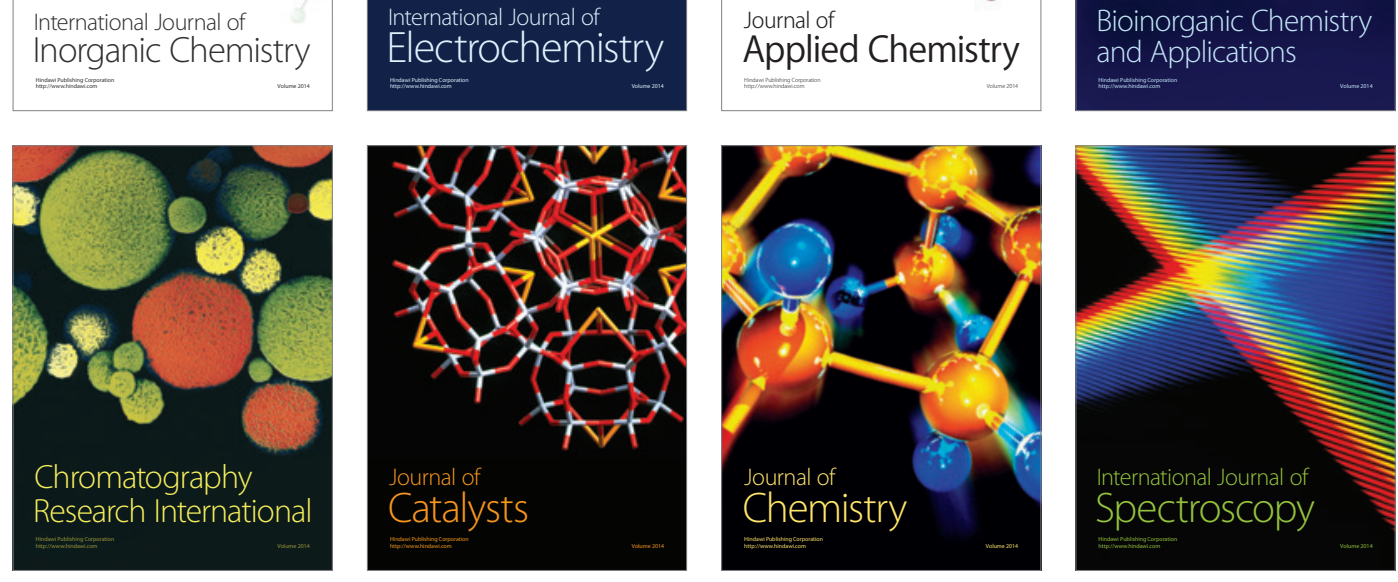